\title{
COMPLEXES OF RUTHENIUM(II) AND RUTHENIUM(III) WITH TERTIARY ARSINES
}

\author{
K. G. SRINIVASAMURTHY, N. M. NANJE GOWDA and G. K. N. REDDY* \\ Department of Chemistry, Bangalore University, Bangalore 560001, India
}

(Received 15 January 1977)

\begin{abstract}
Ruthenium trichloride reacts with stoichiometric amounts of tertiary arsines in boiling ethanol to give paramagnetic complexes, $\mathrm{RuCl}_{3}\left(\mathrm{Ph}_{2} \mathrm{RAs}\right)_{3}(\mathrm{R}=\mathrm{Me}, \mathrm{Et}, \mathrm{Pr}, \mathrm{Bu})$, which react further with 2,2'-bipyridyl(bipy) and $o$-phenanthroline(phen) to yield brick red crystalline products, $\mathrm{RuCl}_{3}(\mathrm{~N}-\mathrm{N})\left(\mathrm{Ph}_{2} \mathrm{RAs}\right)(\mathrm{N}-\mathrm{N}=$ bipy, phen). In the presence of excess arsine $\mathrm{Ru}(\mathrm{III})$ is reduced to $\mathrm{Ru}(\mathrm{II})$, and trichloro-bridged complexes of the formula $\left[\mathrm{Ru}_{2} \mathrm{Cl}_{3}\left(\mathrm{Ph}_{2} \mathrm{RAs}\right)_{6}\right] \mathrm{Cl}$ are formed. These on treatment with carbonylated solutions of rhodium chloride produce yellow crystals of $\left[\mathrm{Ru}_{2} \mathrm{Cl}_{3}\left(\mathrm{Ph}_{2} \mathrm{RAs}_{6}\right]\left[\mathrm{RhCl}_{2}(\mathrm{CO})_{2}\right]\right.$ containing $\mathrm{Ru}(\mathrm{II})$ and $\mathrm{Rh}(\mathrm{I})$. Several dicarbonyl complexes cis $-\mathrm{RuX}_{2}(\mathrm{CO})_{2}\left(\mathrm{Ph}_{2} \mathrm{RAs}\right)_{2}(\mathrm{X}=\mathrm{Cl}, \mathrm{Br} ; \mathrm{R}=\mathrm{Pr}$. Bu) have also been isolated.
\end{abstract}

\section{INTRODUCTION}

Ruthenium(III) halides are known to take part in a variety of reactions with tertiary phosphines and arsines in polar solvents [1-3]. The products may be simple octahedral adducts, of the type $\mathrm{RuX}_{3} \mathrm{~L}_{3}$, or compounds of the type $\mathrm{RuX}_{3} \mathrm{~L}_{2} \mathrm{~S}$ ( $\mathrm{X}=$ halogen; $\mathrm{L}=$ tertiary phosphine or arsine; $\mathrm{S}=$ solvent molecule). Further, it is quite common for ruthenium(III) to be reduced to ruthenium(II) (the polar solvent or the tertiary phosphine or arsine acting as the reducing agent) and give rise to complexes of the formulae $\mathrm{RuX}_{2} \mathrm{~L}_{4}$ and $\mathrm{RuX}_{2} \mathrm{~L}_{3}$. But, very often halo-bridged binuclear complexes of composition $\left[\mathrm{Ru}_{2} \mathrm{X}_{3} \mathrm{~L}_{6}\right] \mathrm{X}$ are obtained [4]. Trichloro-bridged complexes containing two different metal atoms, one of them being ruthenium(II) have also been isolated[5]. The reasons for this varied behaviour are not clearly understood.

In an earlier communication [6] we have reported the reactions of ruthenium trichloride with the tertiary arsines (L), $\mathrm{Ph}_{2} \mathrm{MeAs}$ and $\mathrm{Ph}_{2} \mathrm{EtAs}$, to form complexes of the formulae $\mathrm{RuCl}_{2} \mathrm{~L}_{4}, \mathrm{RuCl}_{2}(\mathrm{CO}) \mathrm{L}_{3}, \mathrm{RuCl}_{2}(\mathrm{CO})_{2} \mathrm{~L}_{2}$, $\left[\mathrm{Ru}_{2} \mathrm{Cl}_{3} \mathrm{~L}_{6}\right] \mathrm{Y}\left(\mathrm{Y}=\mathrm{Cl}, \mathrm{ClO}_{4}, \mathrm{BF}_{4}, \mathrm{BPh}_{4}\right)$ and $\mathrm{RuCl}_{3} \mathrm{~L}_{3}$. We report, here, the details of these investigations and their extension to the arsines $\mathrm{Ph}_{2} \mathrm{PrAs}$ and $\mathrm{Ph}_{2} \mathrm{BuAs}$. We have also investigated the reactions of complexes of the type $\mathrm{RuCl}_{3} \mathrm{~L}_{3}$ with the bidentate heterocyclic nitrogen bases, 2,2'-bipyridyl(bipy) and $o$-phenanthroline (phen).

\section{RESULTS AND DISCUSSION}

Ruthenium trichloride reacts in alcoholic solution with the simple arsines of the type $\mathrm{Ph}_{2} \mathrm{RAs}(\mathrm{R}=\mathrm{Me}, \mathrm{Et}, \mathrm{Pr}$, $\mathrm{Bu}$ ), in the mole ratio $1: 3$, to give paramagnetic nonionic complexes of the formula $\mathrm{RuCl}_{3}\left(\mathrm{Ph}_{2} \mathrm{RAs}\right)_{3}$. We have reported earlier [6] that if the metal halide to arsine ratio is $1: 6$, a binuclear cationic complex of ruthenium(II) of the composition $\left[\mathrm{Ru}_{2} \mathrm{Cl}_{3}\left(\mathrm{Ph}_{2} \mathrm{EtAs}\right)_{6}\right] \mathrm{Cl}$ may be isolated. We now find that better results are obtained if the ratio is $1: 8$, and in this way analogous complexes with the arsines $\mathrm{Ph}_{2} \mathrm{MeAs}, \mathrm{Ph}_{2} \mathrm{PrAs}$ and $\mathrm{Ph}_{2} \mathrm{BuAs}$ have been synthesised. In the case of diphenyl methyl arsine a neutral complex of formula $\mathrm{RuCl}_{2}\left(\mathrm{Ph}_{2} \mathrm{MeAs}\right)_{4}$ is precipitated from the reaction mixture and the ionic complex $\left[\mathrm{Ru}_{2} \mathrm{Cl}_{3}\left(\mathrm{Ph}_{2} \mathrm{MeAs}\right)_{6}\right] \mathrm{Cl}$ can be isolated by concentrating the filtrate. Complexes of the type $\mathrm{RuCl}_{2}\left(\mathrm{Ph}_{2} \mathrm{RAs}\right)_{4}$ could not be isolated in the case of the higher arsines presu- mably because of the higher solubility of these species and their ready conversion to the more stable binuclear cationic species. With diphenyl methyl arsine also, the compound, $\mathrm{RuCl}_{2}\left(\mathrm{Ph}_{2} \mathrm{MeAs}\right)_{4}$, that separates initially, dissolves very slowly in alcohol on refluxing with a small amount of the arsine, is converted to the binuclear complex cation. Further all the binuclear complexes react with $\mathrm{NaY}\left(\mathrm{Y}^{-}=\mathrm{ClO}_{4}{ }^{-}, \mathrm{BF}_{4}{ }^{-}, \mathrm{BPh}_{4}{ }^{-}\right)$in alcohol to give crystalline precipitates of $\left[\mathrm{Ru}_{2} \mathrm{Cl}_{3}\left(\mathrm{Ph}_{2} \mathrm{RAs}\right)_{6}\right] \mathrm{Y}$.

Magnetic susceptibility, conductivity and analytical results support the formulae assigned to these complexes. The complex $\mathrm{RuCl}_{2}\left(\mathrm{Ph}_{2} \mathrm{MeAs}\right)_{4}$ shows a single

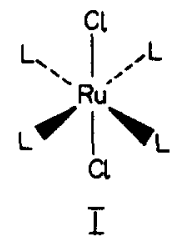

methyl resonance signal at $8.33 \tau$ in the pmr spectrum indicating the equivalence of all the $\mathrm{Ph}_{2} \mathrm{MeAs}$ ligands and so probably has the configuration $\mathrm{I}\left(\mathrm{L}=\mathrm{Ph}_{2} \mathrm{MeAs}\right)$. The binuclear cationic complexes $\left[\mathrm{Ru}_{2} \mathrm{Cl}_{3}\left(\mathrm{Ph}_{2} \mathrm{RAs}\right)_{6}\right] \mathrm{Cl}$ also react with alcoholic solutions of carbonylated rhodium trichloride to give new complexes of the type $\left[\mathrm{Ru}_{2} \mathrm{Cl}_{3}\left(\mathrm{Ph}_{2} \mathrm{RAs}\right)_{6}\right]\left[\mathrm{RhCl}_{2}(\mathrm{CO})_{2}\right]$ containing $\mathrm{Ru}(\mathrm{II})$ in the cation and $\mathrm{Rh}(\mathrm{I})$ in the anion. These products behave as 1:1 lelectrolytes in nitrobenzene, and show two strong $\nu \mathrm{CO}$ bands in the $2000 \mathrm{~cm}^{-1}$ (Table 2) region of the IR, as is typical of cis carbonyl groups. The compounds are obviously formed by the displacement of the $\mathrm{Cl}^{-}$ in $\left[\mathrm{Ru}_{2} \mathrm{Cl}_{3}\left(\mathrm{Ph}_{2} \mathrm{RAs}\right)_{6}\right]^{+}[\mathrm{Cl}]^{-}$by the bulky anion [7] $\left[\mathrm{RhCl}_{2}\left(\mathrm{CO}_{2}\right]^{-}\right.$present in the carbonylated solution of rhodium trichloride [8].

We have reported [9] recently that trihalo complexes of rhodium of the formula $\mathrm{RhX}_{3}\left(\mathrm{Ph}_{2} \mathrm{RAs}\right)_{3}$ undergo facile substitution reactions with the potentially bidentate nitrogen donor ligands bipy or phen (in alcoholic medium), in the presence of hydrohalic acid or perchloric acid, to give cationic complexes of the formula $\left[\mathrm{RhX}_{2}(\mathrm{~N}-\mathrm{N})\right.$ $\left.\left(\mathrm{Ph}_{2} \mathrm{RAs}\right)_{2}\right]^{+}$. It is of interest to find that the analogous complexes of ruthenium(III) $\mathrm{RuCl}_{3}\left(\mathrm{Ph}_{2} \mathrm{RAs}\right)_{3}$ under similar conditions give neutral crystalline complexes of 
composition $\mathrm{RuCl}_{3}(\mathrm{~N}-\mathrm{N})\left(\mathrm{Ph}_{2} \mathrm{RAs}\right)$. It is also noticed that in the absence of $\mathrm{HCl}$ or $\mathrm{HClO}_{4}$ these products are not easily isolable. Hence, it is likely that the substitution reactions are catalysed by hydrogen ions. It may be noted, here, that Ruiz-Ramirez and Stephenson[10], and Natarajan $e t$ al.[11] have prepared analogous complexes starting from the complexes $\mathrm{RuX}_{3} \mathrm{~L}_{2}(\mathrm{MeOH})(\mathrm{X}=\mathrm{Cl}$, $\left.\mathrm{Br} ; \mathrm{L}=\mathrm{Ph}_{3} \mathrm{P}, \mathrm{Ph}_{3} \mathrm{As}\right)$ and $\mathrm{RuCl}_{3}\left(\mathrm{Ph}_{3} \mathrm{As}\right)_{3}$ respectively.

The compounds $\mathrm{RuCl}_{3}(\mathrm{~N}-\mathrm{N})\left(\mathrm{Ph}_{2} \mathrm{RAs}\right)$ give non-conducting solutions in nitrobenzene and show bands due to the coordinated nitrogen ligands in the infrared. The poor solubility and paramagnetic nature of the complexes precluded measurement of their nmr spectra. The magnetic moment values ( $\mu_{\text {eff }}, 2-2.5$ B.M.; Table 1$)$ though rather high for one unpaired electron (spin paired $d^{5}$ electron configuration in an octahedral environment) are nevertheless in the right range for complexes of ruthenium(III) [10] for which a considerable orbital contribution is expected. This is also supported by the ESR spectra, (at room temperature) which show a broad resonance signal with a ' $\mathrm{g}$ ' value around 2.1. Assuming a meridional configuration (structure II)[12] for the complexes $\mathrm{RuCl}_{3}\left(\mathrm{Ph}_{2} \mathrm{RAs}\right)_{3}$ we suggest that the complexes

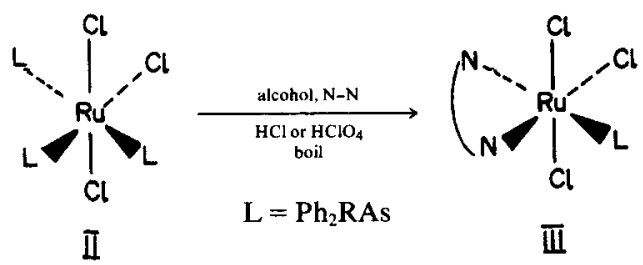

$\mathrm{RuCl}_{3}(\mathrm{~N}-\mathrm{N})\left(\mathrm{Ph}_{2} \mathrm{RAs}\right)$ have configuration III. Further ruthenium(III) $\left(t_{2 g}^{5}\right)$ appears to favour the formation of neutral complexes of the above type in preference to cationic complexes of the type formed by rhodium(III) $\left(t_{2 g}^{6}\right.$ electron configuration). Ruiz-Ramirez and Stephenson[10] have, however, reported recently the isolation of a ruthenium(III) cationic complex of the formula $\left[\mathrm{RuCl}_{2}\right.$ bipy $\left.\left(\mathrm{Ph}_{3} \mathrm{P}\right)_{2}\right] \mathrm{BPh}_{4}$ using methanol as the reaction medium. They suggest that in the polar solvent methanol, preferential replacement of halide ion, rather than $\mathrm{Ph}_{3} \mathrm{P}$ occurs, and the resulting ruthenium(III) cation is precipitated by the bulky anion $\mathrm{BPh}_{4}{ }^{-}$.

We have also synthesised a series of dicarbonyl complexes of ruthenium(II) of stoichiometry $\mathrm{RuX}_{2}(\mathrm{CO})_{2}\left(\mathrm{Ph}_{2} \mathrm{RAs}\right)_{2}(\mathrm{X}=\mathrm{Cl}, \mathrm{Br} ; \mathrm{R}=\mathrm{Pr}, \mathrm{Bu})$ by the addition of the arsine to the pale yellow solution obtained by passing carbon monoxide through an alcoholic solution of ruthenium halide. These compounds are nonelectrolytes in nitrobenzene and show two $\nu \mathrm{CO}$ bands around $2000 \mathrm{~cm}^{-1}$ (Table 2) and so should have configuration IV or $\mathrm{V}$ in analogy with the earlier findings [6].

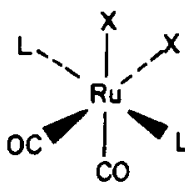

步

$$
\mathbf{L}=\mathrm{Ph}_{2} \mathrm{RAs}
$$

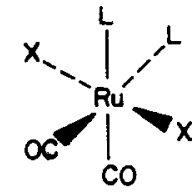

齐

\section{EXPERIMENTAL}

The metal (ruthenium and rhodium) halides were supplied by Johnson Matthey Chemicals Ltd., London. The arsines, $\mathrm{Ph}_{2} \mathrm{RAs}$ $(\mathrm{R}=\mathrm{Me}, \mathrm{Et}, \mathrm{Pr}, \mathrm{Bu})$ were prepared as reported elsewhere [13]. IR spectra (Nujol mulls) were recorded with a Carl Zeiss UR 10 spectrophotometer. Magnetic moments were measured with a Guoy balance using $\mathrm{Co}\left[\mathrm{Hg}(\mathrm{CNS})_{4}\right]$ as the calibrant. Conductivity

Table 1. Physical properties and analytical data of ruthenium(III) complexes

\begin{tabular}{|c|c|c|c|c|c|c|c|}
\hline \multirow[b]{2}{*}{ Compound } & \multirow[b]{2}{*}{ Colour } & \multirow{2}{*}{$\begin{array}{c}\text { M.p. or } \\
\text { Dec. P. }\left({ }^{\circ} \mathrm{C}\right)\end{array}$} & \multirow{2}{*}{$\begin{array}{c}\mu_{\mathrm{eff}}^{\dagger} \\
\text { (B.M.) }\end{array}$} & \multicolumn{4}{|c|}{ Analytical data $(\%) \ddagger$} \\
\hline & & & & (C) & $(\mathrm{H})$ & $(\mathrm{X})$ & $(\mathrm{N})$ \\
\hline $\mathrm{RuCl}_{3}\left(\mathrm{PrPh}_{2} \mathrm{As}_{3}\right)_{3}$ & Black & $186-88$ & 2.41 & $\begin{array}{c}52.9 \\
(52.8)\end{array}$ & $\begin{array}{c}5.1 \\
(5.0)\end{array}$ & $\begin{array}{c}10.4 \\
(10.4)\end{array}$ & - \\
\hline $\mathrm{RuCl}_{3}\left(\mathrm{BuPh}_{2} \mathrm{As}\right)_{3} \S$ & Black & $209-10$ & 2.06 & $\begin{array}{c}50.4 \\
51.3 \\
50.7 \\
(54.1)\end{array}$ & $\begin{array}{c}5.7 \\
5.0 \\
5.1 \\
(5.4)\end{array}$ & $\begin{array}{c}10.3 \\
-\overline{10.2} \\
(10.0)\end{array}$ & - \\
\hline $\mathrm{RuCl}_{3} \operatorname{bipy}\left(\mathrm{MePh}_{2} \mathrm{As}\right)$ & Brickred & $259-61$ & 2.30 & $\begin{array}{c}45.7 \\
(45.4)\end{array}$ & $\begin{array}{c}3.8 \\
(3.5)\end{array}$ & - & $\begin{array}{c}4.6 \\
(4.6)\end{array}$ \\
\hline $\mathrm{RuCl}_{3}$ phen $\left(\mathrm{MePh}_{2} \mathrm{As}\right)$ & Brickred & $292-94$ & 2.00 & $\begin{array}{c}47.3 \\
(47.5)\end{array}$ & $\begin{array}{c}3.7 \\
(3.3)\end{array}$ & $\begin{array}{c}15.9 \\
(16.9)\end{array}$ & $\begin{array}{c}4.4 \\
(4.4)\end{array}$ \\
\hline $\mathrm{RuCl}_{3} \operatorname{bipy}\left(\mathrm{EtPh}_{2} \mathrm{As}\right)$ & Brickred & $215-18$ & 2.47 & $\begin{array}{c}46.7 \\
(46.3)\end{array}$ & $\begin{array}{c}3.8 \\
(3.7)\end{array}$ & - & $\begin{array}{c}4.6 \\
(4.5)\end{array}$ \\
\hline $\mathrm{RuCl}_{3} \mathrm{phen}\left(\mathrm{EtPh}_{2} \mathrm{As}\right)$ & Brickred & $229-32$ & 2.40 & $\begin{array}{c}48.2 \\
(48.3)\end{array}$ & $\begin{array}{c}3.6 \\
(3.6)\end{array}$ & $\begin{array}{c}15.2 \\
(16.5)\end{array}$ & $\begin{array}{c}4.5 \\
(4.3)\end{array}$ \\
\hline $\mathrm{RuCl}_{3} \mathrm{bipy}\left(\mathrm{PrPh}_{2} \mathrm{As}\right)$ & Brickred & $229-32$ & 2.05 & $\begin{array}{c}47.3 \\
(47.2)\end{array}$ & $\begin{array}{c}4.0 \\
(3.9)\end{array}$ & - & $\begin{array}{l}5.0 \\
(4.4)\end{array}$ \\
\hline $\mathrm{RuCl}_{3} \mathrm{phen}\left(\mathrm{PrPh}_{2} \mathrm{As}\right)$ & Brickred & $258-61$ & 2.36 & $\begin{array}{c}49.0 \\
(49.1)\end{array}$ & $\begin{array}{c}3.8 \\
(3.8)\end{array}$ & - & $\begin{array}{c}4.6 \\
(4.2)\end{array}$ \\
\hline $\mathrm{RuCl}_{3} \operatorname{bipy}\left(\mathrm{BuPh}_{2} \mathrm{As}\right)$ & Brickred & $238-40$ & $\|$ & $\begin{array}{l}47.6 \\
(48.0)\end{array}$ & $\begin{array}{c}4.3 \\
(4.2)\end{array}$ & - & $\begin{array}{c}4.4 \\
(4.3)\end{array}$ \\
\hline $\mathrm{RuCl}_{3} \operatorname{phen}\left(\mathrm{BuPh}_{2} \mathrm{As}\right)$ & Brickred & $240-42$ & $\|$ & $\begin{array}{c}50.6 \\
(49.9)\end{array}$ & $\begin{array}{c}4.1 \\
(4.0)\end{array}$ & - & $\begin{array}{c}4.4 \\
(4.2)\end{array}$ \\
\hline
\end{tabular}

†Values for $\mathrm{RuCl}_{3}\left(\mathrm{MePh}_{2} \mathrm{As}\right)_{3}$ and $\mathrm{RuCl}_{3}\left(\mathrm{EtPh}_{2} \mathrm{As}\right)_{3}$ are 2.34 and 2.10 B.M. respectively

$\ddagger$ Calculated values are in parentheses.

$\$$ Although this compound is of low state of purity, bipy and phen derivatives made out of it give satisfactory elemental analysis.

॥Not measured. 
Table 2. Physical properties and analytical data of ruthenium(II) complexes

\begin{tabular}{|c|c|c|c|c|c|c|c|}
\hline \multirow[b]{2}{*}{ Compound } & \multirow[b]{2}{*}{ Colour } & \multirow[b]{2}{*}{$\begin{array}{l}\text { M.p. or } \\
\text { Dec.P. }\end{array}$} & \multirow[b]{2}{*}{$\Lambda^{\dagger}$} & \multirow[b]{2}{*}{$\begin{array}{c}\nu_{\mathrm{co}} \\
\left(\mathrm{cm}^{-1}\right)\end{array}$} & \multicolumn{3}{|c|}{ Analytical data $(\%) \ddagger$} \\
\hline & & & & & (C) & $(\mathrm{H})$ & $(X)$ \\
\hline $\mathrm{RuCl}_{2}\left(\mathrm{MePh}_{2} \mathrm{As}\right)_{4}$ & Pink & $174-76$ & $\S$ & - & $\begin{array}{c}54.4 \\
(54.4)\end{array}$ & $\begin{array}{c}4.5 \\
(4.5)\end{array}$ & $\begin{array}{r}5.4 \\
16.21\end{array}$ \\
\hline$\left[\mathrm{Ru}_{2} \mathrm{Cl}_{3}\left(\mathrm{MePh}_{2} \mathrm{As}\right)_{6}\right] \mathrm{Cl}$ & Yellow & $226-28$ & 23.6 & - & $\begin{array}{c}51.5 \\
(51.8)\end{array}$ & $\begin{array}{c}4.5 \\
(4.3)\end{array}$ & - \\
\hline$\left[\mathrm{Ru}_{2} \mathrm{Cl}_{3}\left(\mathrm{PrPh}_{2} \mathrm{As}\right)_{6}\right] \mathrm{Cl}$ & Yellow & $176-78$ & 25.2 & - & $\begin{array}{c}54.8 \\
(54.6)\end{array}$ & $\begin{array}{c}5.5 \\
(5.2)\end{array}$ & $\begin{array}{r}7.3 \\
(7.2)\end{array}$ \\
\hline$\left[\mathrm{Ru}_{2} \mathrm{Cl}_{3}\left(\mathrm{BuPh}_{2} \mathrm{As}\right)_{6}\right] \mathrm{Cl}$ & Yellow & $174-76$ & 28.2 & - & $\begin{array}{c}55.7 \\
(55.9)\end{array}$ & $\begin{array}{c}5.5 \\
(5.5)\end{array}$ & $\begin{array}{c}6.5 \\
(6.9)\end{array}$ \\
\hline$\left[\mathrm{Ru}_{2} \mathrm{Cl}_{3}\left(\mathrm{MePh}_{2} \mathrm{As}\right)_{6}\right]\left[\mathrm{Rh}\left(\mathrm{CO}_{2} \mathrm{Cl}_{2}\right]\right.$ & Yellow & $205-207$ & 23.6 & $\begin{array}{l}1981 \\
2056\end{array}$ & $\begin{array}{c}47.6 \\
(47.9)\end{array}$ & $\begin{array}{c}4.1 \\
(3.9)\end{array}$ & - \\
\hline$\left[\mathrm{Ru}_{2} \mathrm{Cl}_{3}\left(\mathrm{EtPh}_{2} \mathrm{As}\right)_{6}\right]\left[\mathrm{Rh}(\mathrm{CO})_{2} \mathrm{Cl}_{2}\right]$ & Yellow & $168-70$ & 20.5 & $\begin{array}{l}1986 \\
2060\end{array}$ & $\begin{array}{c}49.5 \\
(49.5)\end{array}$ & $\begin{array}{c}4.3 \\
(4.4)\end{array}$ & $\begin{array}{c}7.8 \\
(8.5)\end{array}$ \\
\hline$\left[\mathrm{Ru}_{2} \mathrm{Cl}_{3}\left(\mathrm{PrPh}_{2} \mathrm{As}\right)_{6}\right] \mid \mathrm{Rh}\left(\mathrm{CO}_{2} \mathrm{Cl}_{2}\right]$ & Yellow & $165-67$ & 22.6 & $\begin{array}{l}1980 \\
2060\end{array}$ & $\begin{array}{c}51.8 \\
(50.8)\end{array}$ & $\begin{array}{l}4.9 \\
(4.7)\end{array}$ & - \\
\hline$\left[\mathrm{Ru}_{2} \mathrm{Cl}_{3}\left(\mathrm{BuPh}_{2} \mathrm{As}_{6}\right]\left[\mathrm{Rh}\left(\mathrm{CO}_{2} \mathrm{Cl}_{2}\right]\right.\right.$ & Yellow & $168-70$ & 22.7 & $\begin{array}{l}1980 \\
2060\end{array}$ & $\begin{array}{c}51.5 \\
(52.2)\end{array}$ & $\begin{array}{c}4.9 \\
(5.1)\end{array}$ & - \\
\hline $\mathrm{RuCl}_{2}\left(\mathrm{CO}_{2}\left(\mathrm{Pr}_{2} \mathrm{Ph}_{2} \mathrm{As}\right)_{2}\right.$ & White & $251-53$ & $\S$ & $\begin{array}{l}1993 \\
2055\end{array}$ & $\begin{array}{l}50.1 \\
(49.8)\end{array}$ & $\begin{array}{l}4.5 \\
(4.4)\end{array}$ & $\ldots$ \\
\hline $\mathrm{RuBr}_{2}\left(\mathrm{CO}_{2}\left(\mathrm{PrPh}_{2} \mathrm{As}_{2}\right.\right.$ & Pale-yellow & $246-48$ & $\S$ & $\begin{array}{l}1990 \\
2053\end{array}$ & $\begin{array}{c}44.6 \\
(44.8)\end{array}$ & $\begin{array}{c}4.0 \\
(4.1)\end{array}$ & - \\
\hline $\mathrm{RuCl}_{2}\left(\mathrm{CO}_{2}\left(\mathrm{BuPh}_{2} \mathrm{As}\right)_{2}\right.$ & White & $178-80$ & $\S$ & $\begin{array}{l}1999 \\
2060\end{array}$ & $\begin{array}{c}50.4 \\
(51.0)\end{array}$ & $\begin{array}{c}4.8 \\
(4.8)\end{array}$ & $\begin{array}{c}8.1 \\
(8.9)\end{array}$ \\
\hline $\mathrm{RuBr}_{2}(\mathrm{CO})_{2}\left(\mathrm{BuPh}_{2} \mathrm{As}\right)_{2}$ & Pale-yellow & $200-202$ & $\S$ & $\begin{array}{l}1983 \\
2053\end{array}$ & $\begin{array}{c}45.9 \\
(45.9)\end{array}$ & $\begin{array}{c}4.5 \\
(4.3)\end{array}$ & $\begin{array}{r}16.7 \\
(18.0)\end{array}$ \\
\hline
\end{tabular}

Molar conductance $\left(\Omega^{-1} \mathrm{~cm}^{2}\right.$ mole $\left.{ }^{-1}\right)$ of $c a \cdot 10^{-3} \mathrm{M}$ solutions in nitrobenzene at $25^{\circ} \mathrm{C}$

$\ddagger$ Calculated values are in parentheses.

$\$$ Non electrolyte.

measurements were made with a Toshniwal conductivity bridge type CL 01.02. Micro-analysis for carbon, hydrogen and nitrogen, were carried out at the University of Sussex, England, and I.I.T., Kanpur. Halogen was estimated by sodium hydroxide fusion and subsequent titration by the Volhard's method. NMR spectra were recorded with a Varian $\mathrm{T}-60$ instrument using $\mathrm{CDCl}_{3}$ as solvent and TMS as internal reference.

Trichloro tris(tertiary arsine) ruthenium(III) compounds: $\mathrm{RuCl}_{3}\left(\mathrm{Ph}_{2} \mathrm{RAs}\right)_{3}$

To an ethanol $(20 \mathrm{ml})$ solution of ruthenium trichloride (I mmole) containing concentrated hydrochloric acid $(1.5 \mathrm{ml}$ ), the arsine ( 3 mmole) in ethanol $(30 \mathrm{ml})$ was added, and the mixture was refluxed on a steam-bath for about $2 \mathrm{hr}$. The compound separated as shining black crystals from the dark solution. It was filtered, washed successively with water and alcohol, and dried in vacuos.

Trichloro 2.2-bipuridyl(or o-phenanthroline) tertiary arsine ru thenium(II) compounds: $\mathrm{RuCl}_{3}(\mathrm{~N}-\mathrm{N})\left(\mathrm{Ph}_{2} \mathrm{RAs}\right)(\mathrm{N}-\mathrm{N}=$ bipy. phen)

To an ethanol $(50 \mathrm{ml})$ suspension of $\mathrm{RuCl}_{3}\left(\mathrm{Ph}_{2} \mathrm{RAs}\right)_{3}$ mmole), bipy or phen ( 1 mmole) was added followed by $\mathrm{HClO}_{4}$ or $\mathrm{HCl}(1.5 \mathrm{ml})$. The mixture was refluxed on a steam-bath for about $5 \mathrm{hr}$. and the brick red crystalline solid that separated (in some cases on concentration of the resulting dark red solution) was filtered, washed successively with water and ether, and dried in vacuo.

Dichloro tetrakis(diphenyl methyl arsine) ruthenium(II): $\mathrm{RuCl}_{2}\left(\mathrm{Ph}_{2} \mathrm{MeAs}\right)_{4}$

To an ethanolic $(20 \mathrm{ml})$ solution of ruthenium trichloride (1 mmole), diphenyl methyl arsine ( 8 mmole) in ethanol $(15 \mathrm{ml})$ was added and the mixture was refluxed on a steam-bath for about $12 \mathrm{hr}$. The shining pink crystals that separated were washed with water, ethanol and dried in vacuo.
Tri- $\mu$-chloro hexakis(tertiary arsine) diruthenium(II) chloride compounds: $\left[\mathrm{Ru}_{2} \mathrm{Cl}_{3}\left(\mathrm{Ph}_{2} \mathrm{RAs}\right)_{6}\right] \mathrm{Cl}$

Ruthenium trichloride $(1 \mathrm{mmole})$ and the tertiary arsine $(8$ mmole) were taken in ethanol $(130 \mathrm{ml})$, and the mixture was refluxed on a steam-bath for about $50 \mathrm{hr}$. The solution was filtered and the filtrate was concentrated under reduced pressure to nearly $3 \mathrm{ml}$. To this, on the dropwise addition of water, the required compound got separated as yellow powder. It was filtered, washed with ether (hexane for $\mathrm{Ph}{ }_{2} \mathrm{PrAs}$ compound) and water, and dried in vacuo.

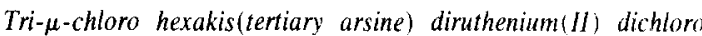
dicarbonyl rhodate( $J)$ compounds: $\quad\left[\mathrm{Ru}_{2}\left(\mathrm{Cl}_{3}\left(\mathrm{Ph}_{2} \mathrm{RAs}\right)_{6}\right]-\right.$ $\left[\mathrm{RhCl}_{2}(\mathrm{CO})_{2}\right]$

Carbon monoxide was passed into a hol alcoholic solution $(5 \mathrm{ml})$ of rhodium trichloride $(0.22 \mathrm{mmole})$ till the solution turned pale yellow. The solution was cooled to about $5^{\circ} \mathrm{C}$ and to this was added an alcoholic solution $(5 \mathrm{ml})$ of $\left[\mathrm{Ru}_{2} \mathrm{Cl}_{3}\left(\mathrm{Ph}_{2} \mathrm{RAs}\right)_{6}\right] \mathrm{Cl}$ $(0.2 \mathrm{mmole})$. The yellow or orange crystalline solid that separated was washed successively with water and ether, and dried in vacuo.

Dihalo dicarbonyl bis(tertiary arsine) ruthenium(II) compounds $\mathrm{RuX}_{2}(\mathrm{CO})_{2}\left(\mathrm{Ph}_{2} \mathrm{RAs}\right)_{2}(\mathrm{X}=\mathrm{Cl}, \mathrm{Br} ; \mathrm{R}=\mathrm{Pr}, \mathrm{Bu})$

Carbon monoxide was passed into a hot methoxyethanol solution $(10 \mathrm{ml})$ of ruthenium halide $(0.3 \mathrm{~mole})$ till the solution turned pale yellow (about $3 \mathrm{hr}$ ). To this, the tertiary arsine $(0.6 \mathrm{mmole})$ was added, and the solution was refluxed for another $10 \mathrm{~min}$ under $\mathrm{CO}$ atmosphere. Dropwise addition of water produced the carbonyl complex as shining white (or pale yellow) crystals. The crystals were washed with water and alcohol, and dried in vacuo.

Acknowledgements - The authors are indebted to Prof. J. Chatt. University of Sussex, England, for micro-analysis and the authorities of the Indian Institute of Science, Bangalore for IR and NMR spectra. They are also thankful to the Chemical Society, London for a research grant (to G.K.N.R.). 


\section{REFERENCES}

1. C. A. McAuliffe, Transition Metal Complexes of Phosphorus, Arsenic and Antimony Ligands' Macmillan, London (1973).

2. W. P. Griffith, The Chemistry of the Rarer Platinum Metals. Interscience, New York, (1967).

3. F. A. Cotton and G. Wilkinson, Advanced Inorganic Chemistry, 3rd Edn. Wiley Eastern. New Delhi, (1976).

4. P. W. Armit, A. S. F. Boyd and T. A. Stephenson, J. Chem. Soc. (Dalton Trans.) 1663 (1975).

5. R. A. Head and J. F. Nixon, J. Chem. Soc. Chem. Commun. 62 (1976)

6. E. G. Leelamani and G. K. N. Reddy, Inorg. Nucl. Chem. Lett. 11, 5 (1975).

7. G. K. N. Reddy and N. M. Nanje Gowda, unpublished results.
8. J. Chatt and B. L. Shaw, J. Chem. Soc. 1437 (1966); R. Colton, R. H. Farthing and J. E. Knapp, Aust. J. Chem. 23, 1351 (1970).

9. N. M. Nanje Gowda and G. K. N. Reddy, J. Inorg. Nucl. Chem. 36, 3745 (1974); Ind. J. Chem. 13, 1064 (1975).

10. L. Ruiz-Ramirez and T. A. Stephenson, J. Chem. Soc. (Dalton Trans.) 2244 (1975).

11. K. Natarajan, R. K. Poddar and U. Agarwala, J. Inorg. Nucl. Chem. 38, 249 (1976).

12. J. Chatt, G. J. Leigh and D. M. P. Mingos, J. Chem. Soc. (A), 1674 (1969).

13. N. M. Nanje Gowda, Ph.D. Thesis, Bangalore University (1975). 